\title{
Adaptasi Peningkatan Resiliensi Aspek Sosial Berdasarkan Konsep Climate and Disaster Resilience Initiative (CDRI) di Wilayah Perkotaan Benjeng dan Cerme, Gresik
}

\author{
Mega Utami Ciptaningrum ${ }^{1}$ \\ Adjie Pamungkas ${ }^{2}$ \\ ${ }^{1}$ Alumni Departemen Perencanaan Wilayah dan Kota, FTSP-ITS Surabaya \\ Email: meganingr@gmail.com \\ ${ }^{2}$ Staf pengajar Departemen Perencanaan Wilayah dan Kota, FTSP-ITS Surabaya \\ Email: adjie@urplan.its.ac.id atau adjie.difi@gmail.com
}

\begin{abstract}
ABSTRAK
Banjir luapan Kali Lamong Kabupaten Gresik berdampak pada dua wilayah perkotaan Benjeng dan Cerme. Dalam menghadapi bencana, saat ini konsep resiliensi menjadi tren untuk mengurangi dampak kerugian yang ditimbulkan karena lebih menghemat biaya. Penelitian sebelumnya menunjukkan bahwa wilayah perkotaan Benjeng dan Cerme memiliki resiliensi yang tinggi terhadap banjir, namun masih perlu adanya penguatan dan peningkatan pada beberapa aspek sosial. Sehingga dibutuhkan arahan adaptasi peningkatan resiliensi sosial di wilayah perkotaan Benjeng dan Cerme.

Metode analisis yang digunakan dalam penelitian ini adalah metode Content Analysis. Hasil penelitian menunjukkan bahwa terdapat 43 arahan adaptasi peningkatan resiliensi untuk wilayah perkotaan Benjeng dan 19 arahan untuk wilayah perkotaan Cerme. Fase mitigasi dan learning adaptation menjadi titik berat dalam meningkatkan risiliensi kedua wilayah perkotaan.
\end{abstract}

Kata Kunci : Adaptasi, Dimensi sosial, Perkotaan, Resiliensi. 


\section{PENDAHULUAN}

Sebanyak dua per tiga bencana yang terjadi di Indonesia adalah bencana banjir (Indawati, 2015). Banjir menimbulkan kerugian terhadap wilayah yang terdampak. Perlu adanya resiliensi dari suatu wilayah dalam menghadapi bencana untuk mengurangi kerugian yang dialami. Resiliensi merupakan kemampuan sistem atau masyarakat yang terdampak bencana untuk memulihkan diri secara cepat dan efisien (UNISDR, 2009). Resiliensi merupakan kombinasi dari 3 karakter utama yaitu kemampuan untuk menahan perubahan dan tekanan (absorb shock), kemampuan system kembali ke keadaan sebelum bencana (bounce back), dan kemampuan system untuk belajar dan beradaptasi (learning and adaptation) (Barrett dan Constas, 2013). Resiliensi sosial menjadi kunci utama karena berkaitan langsung dengan masyarakat, bukan berasal dari infrastruktur fisik atau perlengkapan peralatan dalam menghadapi bencana (Aldrich, 2017).

Kabupaten Gresik merupakan salah satu wilayah yang sering dilanda banjir yang salah satu penyebabnya adalah luapan Kali Lamong. Wilayah perkotaan yang terdampak luapan Kali Lamong adalah Wilayah perkotaan Benjeng dan Wilayah perkotaan Cerme.

Penilaian resiliensi sosial terhadap banjir berdasarkan konsep Climate and Disaster Resilience Initiative (CDRI) menunjukkan bahwa wilayah perkotaan Wilayah perkotaan Benjeng dan Cerme berada pada kategori tinggi. Wilayah perkotaan Benjeng memiliki nilai resiliensi sosial 3,87, sedangkan Wilayah perkotaan Cerme 4,29 (Ciptaningrum \& Pamungkas, 2017). Namun meskipun demikian terdapat beberapa variabel yang masih perlu ditingkatkan untuk mengoptimalkan resiliensi sosial yang telah ada, yaitu di Wilayah perkotaan Benjeng meliputi 6 variabel; populasi penduduk yang mengalami sakit akibat pencemaran air banjir (waterborne disease), tersedianya program atau pelatihan kesadaran terhadap bencana, akses internet, jumlah penduduk yang tergabung dalam komunitas, jumlah penduduk yang berpartisipasi dalam kegiatan sosial serta jumlah penduduk yang berpartisipasi dalam kegiatan sosial. Sedangkan variabel resiliensi sosial yang masih perlu ditingkatkan di Wilayah perkotaan Cerme meliputi 3 variabel; partisipasi dalam kelompok sosial serta kemampuan penduduk dalam proses pengambilan keputusan (level demokrasi). Untuk mengoptimalkan resiliensi sosial masyarakat dalam menghadapi banjir, diperlukannya arahan adaptasi yang sesuai dengan karakteristik sosial di masingmasing wilayah penelitian. Menurut Asian Disaster Reduction Center, proses adaptasi pada konsep Disaster Risk Management (DRM) terbagi dalam 4 fase penting yaitu pencegahan/ mitigasi (prevention/ mitigation), kesiapsiagaan (preparedness), respon (response) dan rehabilitasi/ rekonstruksi (rehabilitation/ reconstruction). Dalam penelitian ini arahan adaptasi yang dihasilkan akan dikategorikan ke dalam 3 karakter resiliensi dan 4 fase adaptasi.

\section{METODE}

\section{A. Metode Pengumpulan Data}

Metode pengumpulan data yang digunakan dalam penelitian ini adalah metode survei sekunder dan survei primer. survei sekunder dilakukan untuk memperoleh referensi upaya adaptasi peningkatan resiliensi sosial dari tinjauan literatur. Sedangkan survei primer dilakukan dengan In-depth Interview kepada stakeholder terpilih. In-depth Interview dilakukan untuk mengumpulkan informasi tanggapan stakeholder terhadap arahan adaptasi peningkatan resiliensi. Stakeholder internal terpilih yang berkaitan dengan penelitian di Wilayah perkotaan Benjeng dari pihak pemerintah adalah dari kantor kecamatan (Ga1), kantor desa (Ga2), dan Badan Permusyawaratan Desa (Ga3). Dari pihak masyarakat adalah dari pengurus RW (Ca1) dan pengurus RT 
(Ca2). Sedangkan dari pihak swasta adalah Gabungan Kelompok Tani (Pa1). Begitu pula dengan Wilayah perkotaan Cerme, stakeholder dari pihak pemerintah adalah dari kantor kecamatan (Gb1), kantor desa (Gb2), dan Badan Permusyawaratan Desa (Gb3). Dari pihak masyarakat adalah dari pengurus RW (Cb1) dan pengurus RT (Cb2). Sedangkan dari pihak swasta adalah Gabungan Kelompok Tani (Pb1). Stakeholder eksternal terpilih adalah Kepala BPBD Kabupaten Gresik (G1), akademisi (C1), tenaga medis Puskesmas Benjeng (H1). Wilayah penelitian meliputi 2 wilayah perkotaan sebagaimana ditunjukkan pada gambar berikut.

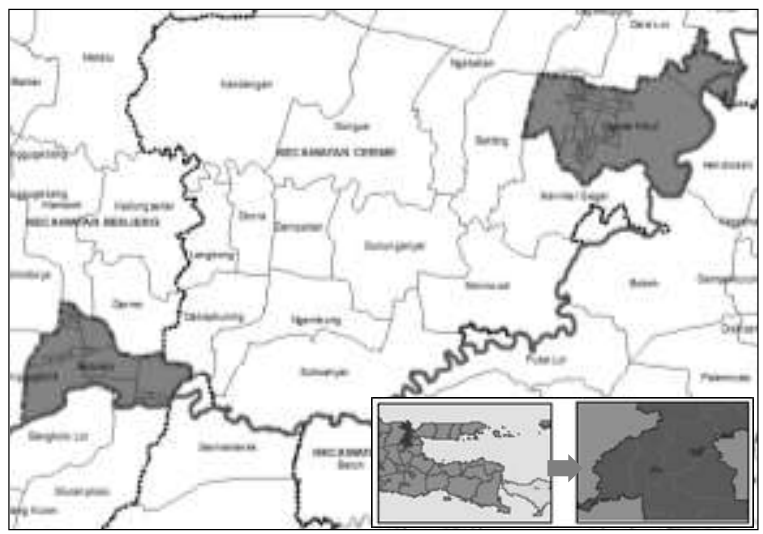

Gambar 1. Peta wilayah penelitian

\section{B. Metode Analisis Data}

Data hasil In-depth interview dianalisis menggunakan metode content analysis dengan tahapan sebagai berikut.

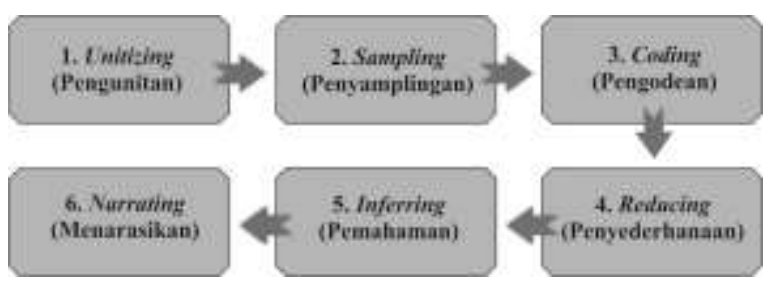

Gambar 2. Tahap Content Analysis

\section{Unitizing (pengunitan)}

Menentukan unit observasi dan unit analisis untuk mendapatkan data yang sesuai dengan tujuan penelitian. Unit observasi pada penelitian ini adalah transkrip wawancara dan unit analisis adalah kalimat dalam transkrip wawancara.

\section{Sampling (penyamplingan)}

Pembatasan observasi data melalui pembatasan jumlah yang menjadi sumber data utama. Stakeholder terpilih hanyalah stakeholder yang memiliki kepentingan dan pengaruh yang cenderung tinggi di wilayah penelitian.

\section{Coding (pengodean)}

Menandai informasi-informasi penting terkait dengan tujuan penelitian dalam data teks. Pengodean akan dipilah berdasarkan karakteristik unit, menyesuaikan, kemudian meng-highlight pada tiap transkrip wawancara kemudian dimasukkan dalam tabel/matriks analisis. Pengodean dilakukan berdasarkan prosedur semantical content analysis, yaitu dengan mengklasifikasikan tandatanda berdasarkan makna yang dimiliki.

4. Reducing (penyederhanaan)

Penyederhanaan dilakukan dengan teknik assertion analysis, dengan memperlihatkan frekuensi dari beberapa objek tertentu yang dicirikan dengan cara tertentu. Sehingga dapat diketahui arahan yang sesuai untuk peningkatan resiliensi masyarakat.

\section{Inferring (pemahaman)}

Pemahaman terhadap data diperlukan untuk menarasikan arahan untuk selanjutnya disimpulkan. Pemahaman tersebut dilakukan dengan melihat frekuensi unit analisis yang mengindikasikan hal yang sama.

\section{Narrating (menarasikan)}

Merupakan hasil penarasian dari tahap sebelumnya yang mampu menjawab pertanyaan penelitian mengenai adaptasi resiliensi masyarakat, baik yang merupakan kondisi eksisting maupun arahan peningkatan resiliensi. Hasil Content Analysis yang telah diperoleh dipadukan juga dengan kebijakan lain yang mendukung, sehingga diharapkan dapat memperoleh hasil arahan yang sesuai dengan kondisi wilayah studi. Setelah diperoleh beberapa arahan yang sesuai. Selanjutnya arahan-arahan tersebut diklasifikasikan berdasarkan 4 fase adaptasi, yaitu mitigasi, kesiapsiagaan, 
respon dan rehabilitasi. Selain itu arahanarahan tersebut juga diklasifikasikan berdasarkan 3 karakter utama resiliensi, yaitu besarnya kejutan yang dapat diserap oleh sistem (absorb shock), kemampuan sistem untuk mengorganisasikan diri (bounce back) serta kemampuan sistem untuk belajar dan beradaptasi (learning and adaptation).

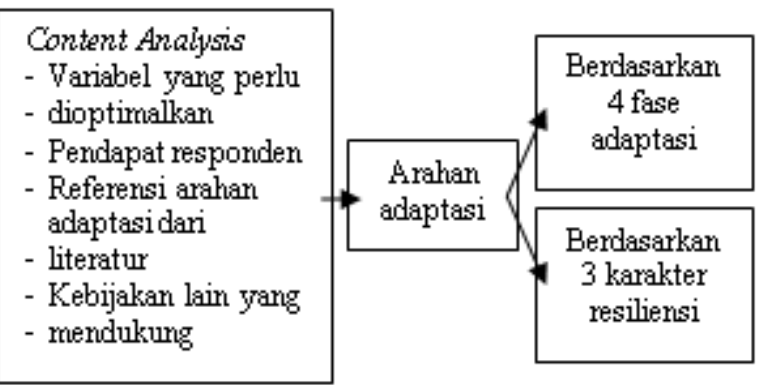

Gambar 3. Proses Analisis Arahan Adaptasi

\section{HASIL}

\section{A. Referensi Upaya Adaptasi}

Berdasarkan hasil tinjauan literatur, diperoleh beberapa arahan upaya adaptasi sosial yang dapat dilakukan. Karena memiliki beberapa persamaan karakter resiliensi sosial, maka terdapat pula beberapa referensi arahan adaptasi resiliensi yang sama pada kedua wilayah penelitian sebagaimana ditunjukkan pada tabel berikut.

\section{Tabel 1.}

Referensi upaya adaptasi sosial dalam menghadapi banjir di kedua wilayah penelitian

\begin{tabular}{|c|c|}
\hline $\begin{array}{c}\text { Upaya adaptasi dari } \\
\text { literatur }\end{array}$ & Sumber \\
\hline \multicolumn{2}{|c|}{$\begin{array}{l}\text { Jumlah penduduk yang tergabung dalam } \\
\text { komunitas serta jumlah penduduk yang } \\
\text { berpartisipasi dalam kegiatan sosial }\end{array}$} \\
\hline $\begin{array}{lr}\text { Dilibatkannya } & \text { masyarakat } \\
\text { mendirikan } & \text { tenda } \\
\text { pengungsian } & \end{array}$ & $\begin{array}{l}\text { Aminudin, } 2013 \\
\text { dalam Nurhaimi } \\
\text { dan Rahayu, } 2014\end{array}$ \\
\hline $\begin{array}{l}\text { Dilibatkannya masyarakat } \\
\text { mendirikan dapur umum }\end{array}$ & $\begin{array}{lr}\text { Aminudi } & (2013) \\
\text { dalam } & \text { Nurhaimi } \\
\text { dan Rahayu }(2014)\end{array}$ \\
\hline $\begin{array}{l}\text { Dilibatkannya masyarakat } \\
\text { dalam pendistribusian } \\
\text { bantuan }\end{array}$ & $\begin{array}{lr}\text { Aminudi } & (2013) \\
\text { dalam } & \text { Nurhaimi } \\
\text { dan Rahayu (2014) }\end{array}$ \\
\hline
\end{tabular}

\begin{tabular}{|l|l|}
\hline \multicolumn{1}{|c|}{$\begin{array}{c}\text { Upaya adaptasi dari } \\
\text { literatur }\end{array}$} & \multicolumn{1}{c|}{ Sumber } \\
\hline Tolong-menolong & Huda, 2014 \\
\hline $\begin{array}{l}\text { Mengupayakan norma tetap } \\
\text { berjalan dengan baik }\end{array}$ & Huda, 2014 \\
\hline Kerja bakti kelompok & $\begin{array}{l}\text { Nurhaimi dan } \\
\text { Rahayu, 2014 }\end{array}$ \\
\hline $\begin{array}{l}\text { Pembentukan dan } \\
\text { berdasarkan } \\
\text { kesamaan/kedekatan wilayah }\end{array}$ & \multicolumn{2}{c|}{ dan } \\
\hline $\begin{array}{l}\text { Pembentukan kelompok } \\
\text { berdasarkan kesamaan hobi/ } \\
\text { kebutuhan }\end{array}$ & $\begin{array}{l}\text { Sander } \\
\text { Lowney, 2006 }\end{array}$ \\
\hline $\begin{array}{l}\text { Perayaan tertentu } \\
\text { dan }\end{array}$ \\
\hline
\end{tabular}

Referensi arahan adaptasi di atas diperuntukkan bagi kedua wilayah penelitian karena kesamaan karakternya. Referensi upaya-upaya adaptasi tersebut memiliki persamaan tujuan yaitu untuk meningkatkan jumlah penduduk yang tergabungdalamkomunitassertajumlahpend uduk yang berpartisipasi dalam kegiatan sosial.

\section{Tabel 2.}

Referensi upaya adaptasi sosial dalam menghadapi banjir khusus untuk wilayah perkotaan Benjeng

\begin{tabular}{|c|c|}
\hline $\begin{array}{l}\text { Upaya adaptasi dari } \\
\text { literatur }\end{array}$ & Sumber \\
\hline \multicolumn{2}{|c|}{$\begin{array}{l}\text { Populasi penduduk yang mengalami sakit } \\
\text { akibat pencemaran air banjir (waterborne } \\
\text { disease) }\end{array}$} \\
\hline $\begin{array}{l}\text { Menggunakan air bersih } \\
\text { dengan efisien }\end{array}$ & $\begin{array}{lr}\text { Aminudi } & (2013) \\
\text { dalam } & \text { Nurhaimi } \\
\text { dan Rahayu (2014) }\end{array}$ \\
\hline $\begin{array}{l}\text { Tidak membiarkan anak- } \\
\text { anak bermain di air banjir }\end{array}$ & $\begin{array}{l}\text { Ariantoni, Paresti } \\
\text { \& Hidayati, } 2009\end{array}$ \\
\hline $\begin{array}{l}\text { Menjaga agar sistem } \\
\text { pembuangan limbah dan air } \\
\text { kotor tetap bekerja }\end{array}$ & $\begin{array}{l}\text { Ariantoni, Paresti } \\
\text { \& Hidayati, } 2009\end{array}$ \\
\hline $\begin{array}{l}\text { Sosialisasi dan advokasi } \\
\text { adaptasi sektor kesehatan }\end{array}$ & \begin{tabular}{lr} 
Peraturan & Menteri \\
tentang & Strategi \\
Adaptasi & Sektor \\
Kesehatan & terhadap \\
Dampak Perubahan \\
\multicolumn{2}{l}{ Iklim, 2009 }
\end{tabular} \\
\hline $\begin{array}{l}\text { Peningkatan pelayanan } \\
\text { kesehatan yang telah ada }\end{array}$ & $\begin{array}{l}\text { Divisi } \\
\text { Penanggulangan } \\
\text { Bencana PMI } \\
\text { Pusat, } 2007\end{array}$ \\
\hline $\begin{array}{ll}\text { Mendirikan pos } & \text { kesehatan } \\
\text { dan bantuan } & \text { kesehatan }\end{array}$ & $\begin{array}{lr}\text { Aminudi, } & 2013 \\
\text { dalam } & \text { Nurhaimi } \\
\end{array}$ \\
\hline
\end{tabular}




\begin{tabular}{|c|c|}
\hline $\begin{array}{c}\text { Upaya adaptasi dari } \\
\text { literatur }\end{array}$ & Sumber \\
\hline darurat & dan Rahayu, 2014 \\
\hline \multicolumn{2}{|c|}{$\begin{array}{l}\text { Tersedianya program atau pelatihan kesadaran } \\
\text { terhadap bencana }\end{array}$} \\
\hline Edukasi terhadap masyarakat & $\begin{array}{ll}\text { Nurhaimi } & \text { dan } \\
\text { Rahayu, 2014 } & \end{array}$ \\
\hline $\begin{array}{l}\text { Peningkatan kesadaran pada } \\
\text { kemungkinan perubahan } \\
\text { pola bercocok tanam }\end{array}$ & $\begin{array}{l}\text { Divisi } \\
\text { Penanggulangan } \\
\text { Bencana PMI } \\
\text { Pusat, 2007 }\end{array}$ \\
\hline $\begin{array}{l}\text { Pelajaran berenang untuk } \\
\text { anak-anak }\end{array}$ & $\begin{array}{l}\text { Divisi } \\
\text { Penanggulangan } \\
\text { Bencana, PMI } \\
\text { Pusat, 2007 }\end{array}$ \\
\hline $\begin{array}{lr}\text { Penyusunan } & \text { dan } \\
\text { penyampaian } & \text { rencana } \\
\text { kesiapsiagaan } & \\
\end{array}$ & Khan, 2008 \\
\hline Pembuatan rute evakuasi & UNISDR, 2009 \\
\hline $\begin{array}{l}\text { Membentuk kelompok } \\
\text { masyarakat tanggap bencana } \\
\text { banjir }\end{array}$ & $\begin{array}{l}\text { Ariantoni, Paresti } \\
\text { dan Hidayati, } 2009\end{array}$ \\
\hline \multicolumn{2}{|l|}{ Akses internet } \\
\hline $\begin{array}{lr}\text { Pelaksanaan } & \text { sistem } \\
\text { informasi banjir langsung } \\
\text { kepada masyarakat }\end{array}$ & $\begin{array}{l}\text { Ariantoni, Paresti } \\
\text { dan Hidayati, } 2009\end{array}$ \\
\hline
\end{tabular}

Referensi arahan adaptasi di atas khusus untuk wilayah perkotaan Benjeng berdasarkan karakter resiliensi sosialnya. Referensi upaya-upaya adaptasi tersebut bertujuan untuk mengurangi populasi penduduk yang mengalami sakit akibat pencemaran air banjir (waterborne disease) dan untuk mendukug lancarnya ketersediaan program atau pelatihan kesadaran terhadap bencana.

\section{Tabel 3.}

Referensi upaya adaptasi sosial dalam menghadapi banjir khusus untuk wilayah perkotaan Cerme

\begin{tabular}{|l|l|}
\hline \multicolumn{1}{|c|}{$\begin{array}{c}\text { Upaya adaptasi dari } \\
\text { literatur }\end{array}$} & \multicolumn{1}{c|}{ Sumber } \\
\hline $\begin{array}{l}\text { Kemampuan penduduk dalam proses } \\
\text { pengambilan keputusan (level demokrasi) }\end{array}$ \\
\hline Pembuatan website desa & $\begin{array}{l}\text { kuripan- } \\
\text { penengahan.desa.i } \\
\end{array}$ \\
& d, 2016 \\
\hline Membangun ruang publik & Evans \& Boyte, \\
untuk demokrasi & 1992 dalam \\
& Imagawa, Porter, \\
& Sulis, Wozniak, \& \\
& Minerbi, 2016 \\
\hline Memberikan dukungan & Huda, 2014 \\
\hline
\end{tabular}

\begin{tabular}{|l|l|}
\multicolumn{1}{|c|}{$\begin{array}{c}\text { Upaya adaptasi dari } \\
\text { literatur }\end{array}$} & Sumber \\
\hline $\begin{array}{l}\text { material maupun non- } \\
\text { material terhadap komunitas }\end{array}$ & \\
\hline $\begin{array}{l}\text { Mengintegrasikan } \\
\text { keterlibatan institusi dan } \\
\text { masyarakat dalam } \\
\text { perencanaan }\end{array}$ & Huda, 2014 \\
\hline
\end{tabular}

Referensi arahan adaptasi di atas khusus untuk wilayah perkotaan Cerme berdasarkan karakter resiliensi sosialnya. Referensi upaya-upaya adaptasi tersebut bertujuan untuk meningkatkan kemampuan penduduk dalam proses pengambilan keputusan (level demokrasi)

Arahan-arahan adaptasi tersebut selanjutnya ditanyakan kepada stakeholder terpilih apakah sesuai untuk diterapkan di wilayah penelitian atau tidak. Kemudian disesuaikan juga dengan kebijakankebijakan lain yang berkaitan.

\section{B. Perumusan Arahan Adaptasi Wilayah perkotaan Benjeng}

Berdasarkan hasil Content Analysis terhadap pendapat stakeholder terpilih, terdapat beberapa informasi penting utamadi Wilayah perkotaan Benjeng untuk merumuskan arahan adaptasi peningkatan resiliensi.

\section{Tabel 4.}

Contoh proses penentuan arahan adaptasi pada variabel menggunakan air bersih dengan efisien

\begin{tabular}{|c|c|c|}
\hline $\begin{array}{c}\text { Upaya } \\
\text { adaptasi dari } \\
\text { literatur }\end{array}$ & Indikasi & $\begin{array}{l}\text { Kondisi } \\
\text { Eksisting }\end{array}$ \\
\hline $\begin{array}{l}\text { Menggunakan } \\
\text { air bersih } \\
\text { dengan } \\
\text { efisien }\end{array}$ & 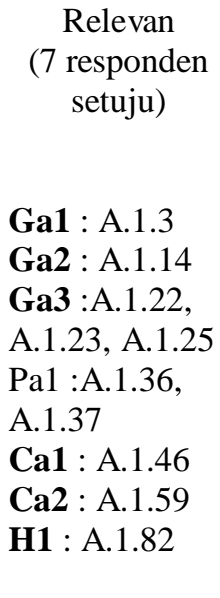 & $\begin{array}{c}\text { Telah ada tetapi } \\
\text { belum } \\
\text { maksimal } \\
\left(\begin{array}{c}7 \text { responden } \\
\text { setuju) }\end{array}\right. \\
\text { Ga1 : A.1.4 } \\
\text { Ga2 : A.1.15 } \\
\text { Ga3 :A.1.22, } \\
\text { A.1.23, A.1.25 } \\
\text { Pa1 :A.1.36, } \\
\text { A.1.37 } \\
\text { Ca1 : A.1.47, } \\
\text { A.1.48 } \\
\text { Ca2 : A.1.60, }\end{array}$ \\
\hline
\end{tabular}




\begin{tabular}{|l|c|c|}
$\begin{array}{c}\text { Upaya } \\
\text { adaptasi dari } \\
\text { literatur }\end{array}$ & Indikasi & $\begin{array}{c}\text { Kondisi } \\
\text { Eksisting }\end{array}$ \\
\hline & & A.1.61 \\
H1 : A.1.82
\end{tabular}

Hasil In-depth Interview terhadap 7 stakeholder yang berkaitan dengan penyakit yang ditimbulkan akibat banjir menunjukkan bahwa seluruh stakeholder berpendapat upaya penggunaan air bersih dengan efisien sangat relevan dan dibutuhkan untuk diterapkan di wilayah perkotaan Benjeng. Selain itu upaya tersebut juga sudah berusaha diterapkan di wilayah penelitian. Kesesuaian penerapan arahan adaptasi tersebut juga didukung dengan beberapa kebijakan yang salah satunya adalah UU No.24 Th 2007 tentang Penanggulangan Bencana Pasal 53 yang menyebutkan perlunya bantuan pemenuhan kebutuhan dasar bagi korban bencana berupa kebutuhan air bersih dan sanitasi.

Saat ini mayoritas masyarakat di wilayah perkotaan Benjeng mengandalkan sumur sebagai sumber pemenuhan air bersih. Dalam kondisi banjir, sebagian masyarakat masih menggunakan air sumur secara langsung, air sumur yang telah diletakkan dalam tendon sebagai persiapan sebelum banjir, membeli air galon, membeli air PDAM yang dijual dalam jeriken maupun telah terhubung oleh jaringan PDAM. Lamanya proses pemasangan pipa PDAM menjadi kendala di beberapa desa di Kecamatan Benjeng, termasuk Wilayah perkotaan Benjeng. Sehingga berdasarkan pertimbangan dari stakeholder terpilih dan didukung dengan kebijakan yang berkaitan maka arahan adaptasi yang sesuai adalah sebagai berikut :

- Koordinasi antara masyarakat, pemerintah daerah, BPBD dan dinas kesehatan dalam penanganan banjir

- Pendataan terhadap kasus penyakit yang timbul akibat banjir oleh Puskesmas Benjeng

- Melakukan pemeriksaan kualitas air bersih khususnya air sumur

- Perlu dilakukannya sosialisasi terkait bahaya penggunaan air sumur yang tercemar air banjir

- Memberikan solusi perbaikan kualitas air berupa pemberian bubuk penjernih dan desinfektan yang aman digunakan

- Bantuan air bersih menggunakan mobil tangki air

- Koordinasi percepatan pemasangan jaringan pipa PDAM dengan pihakpihak terkait

Sementara itu arahan untuk variabel penting lainnya adalah sebagai berikut.

Tabel 5.

Contoh penentuan arahan adaptasi pada variabel edukasi terhadap masyarakat

\begin{tabular}{|c|c|c|}
\hline $\begin{array}{c}\text { Upaya } \\
\text { adaptasi } \\
\text { dari } \\
\text { literatur }\end{array}$ & Indikasi & $\begin{array}{l}\text { Kondisi } \\
\text { Eksisting }\end{array}$ \\
\hline $\begin{array}{l}\text { Edukasi } \\
\text { terhadap } \\
\text { masyarakat }\end{array}$ & $\begin{array}{l}\begin{array}{c}\text { Relevan } \\
\text { (7 responden } \\
\text { setuju) }\end{array} \\
\\
\text { Ga1 : A.2.8 } \\
\text { Ga2 : A.2.9, } \\
\text { A.2.10 } \\
\text { Ga3 : A.2.21 } \\
\text { Pa1 : A.2.26, } \\
\text { A.2.27 } \\
\text { Ca2 : A.2.51 } \\
\text { G1 : A.2.86, } \\
\text { A.2.87, A.2.88, } \\
\text { A.2.89, A.2.90 } \\
\text { A.2.92, A.2.93, } \\
\text { A.2.94 } \\
\text { C1 : A.2.97, }\end{array}$ & $\begin{array}{c}\text { Telah ada tetapi } \\
\text { belum } \\
\text { maksimal } \\
\left(\begin{array}{c}\text { responden } \\
\text { setuju })\end{array}\right. \\
\text { Ga1 : A.2.8 } \\
\text { Ga2 : A. } 2.9, \\
\text { A.2.10, A.2.11, } \\
\text { A.2.17 } \\
\text { Ga3 : A.2.20 } \\
\text { Pa1 : A.2.26, } \\
\text { A.2.27 } \\
\text { Ca2 : A.2.51 } \\
\text { G1 : A.2.86, } \\
\text { A.2.87, A.2.88, } \\
\text { A.2.89, A.2.90 } \\
\text { A.2.92, A.2.93, }\end{array}$ \\
\hline
\end{tabular}




\begin{tabular}{l}
$\begin{array}{c}\text { Upaya } \\
\text { adaptasi } \\
\text { dari } \\
\text { literatur }\end{array}$ \\
\hline
\end{tabular}

Sosialisasi dan pengobatan sudah sering dilakukan bersamaan dengan kegiatan posyandu rutin yang diadakan per dusun oleh bidan dan perawat desa. Dalam kaitannya dengan banjir, sosialisasi mengenai penyakit yang ditimbulkan oleh banjir dan cara penanganannya masih sangat kurang, sehingga masih perlu ditingkatkan lagi. Hal ini dikarenakan banjir di Wilayah perkotaan Benjeng dianggap tidak terlalu berdampak besar jika dibandingkan dengan banjir di desa lain di Kecamatan Benjeng, seperti Desa Sedapurklagen, Deliksumber dan Kedungrukem. Serta diperlukan pula sosialisasi yang menjangkau pelajar untuk meminimalisir jumlah penyakit akibat banjir yang mayoritas adalah anak-anak. Sehingga berdasarkan pertimbangan dari stakeholder terpilih dan didukung dengan kebijakan yang berkaitan maka arahan adaptasi yang sesuai adalah sebagai berikut :

- Peningkatan sosialisasi mengenai penyakit yang ditimbulkan oleh banjir yang meliputi penyebab dan cara penanganannya kepada masyarakat

\section{Perumusan Arahan Adaptasi Wilayah perkotaan Cerme}

Berdasarkan hasil Content Analysis terhadap pendapat stakeholder terpilih, terdapat beberapa informasi penting utama di Wilayah perkotaan Cerme untuk merumuskan arahan adaptasi peningkatan resiliensi.

Tabel 6.

Arahan adaptasi variabel pembentukan kelompok berdasarkan kedekatan wilayah

\begin{tabular}{|c|c|c|}
\hline $\begin{array}{c}\text { Upaya adaptasi } \\
\text { dari literatur }\end{array}$ & Indikasi & $\begin{array}{l}\text { Kondisi } \\
\text { Eksisting }\end{array}$ \\
\hline $\begin{array}{l}\text { Pembentukan } \\
\text { kelompok } \\
\text { berdasarkan } \\
\text { kesamaan/kedekatan } \\
\text { wilayah }\end{array}$ & $\begin{array}{l}\begin{array}{c}\text { Relevan } \\
\quad(5\end{array} \\
\begin{array}{c}\text { responden } \\
\text { setuju })\end{array} \\
\text { Gb2 : } \\
\text { A.4.95 } \\
\text { Gb3 : } \\
\text { A.4.111, } \\
\text { A.4.112 } \\
\text { Pb1 : } \\
\text { A.4.121 } \\
\text { Cb1 : } \\
\text { A.4.137 } \\
\text { Cb2 : } \\
\text { A.4.154, } \\
\text { A.4.155, } \\
\text { A.4.157 }\end{array}$ & $\begin{array}{c}\text { Telah ada } \\
\text { tetapi belum } \\
\text { maksimal } \\
\text { (5 responden } \\
\text { setuju) } \\
\text { Gb2 : } \\
\text { A.4.95 } \\
\text { Gb3 : } \\
\text { A.4.111, } \\
\text { A.4.112 } \\
\text { Pb1 : } \\
\text { A.4.121 } \\
\text { Cb1 : } \\
\text { A.4.137, } \\
\text { A.4.138, } \\
\text { A.4.143 } \\
\text { Cb2 : } \\
\text { A.4.154, } \\
\text { A.4.155, } \\
\text { A. } 4.157\end{array}$ \\
\hline \multicolumn{3}{|c|}{$\begin{array}{l}\text { Kebijakan pendukung } \\
\text { 1. Peraturan Menteri Dalam Negeri No } 5 \text { Tahun } \\
2007 \text { tentang Pedoman Penataan Lembaga } \\
\text { Kemasyarakatan Pasal 3, Pasal 5, Pasal 7yang } \\
\text { membahas tentang pentingnya lembaga } \\
\text { kemasyarakatan beserta dengan jenis-jenisnya }\end{array}$} \\
\hline
\end{tabular}

Kelompok masyarakat berdasarkan kedekatan wilayah yang telah terbentuk adalah PKK, RT/RW dan Karang Taruna. Kegiatan RT yang telah secara rutin dilaksanakan adalah kegiatan arisan, selain itu ada pula arisan desa yang merupakan kumpulan pengurus RT. Namun untuk kegiatan PKK dan Karang Taruna belum begitu aktif berjalan. Karang Taruna hanya melakukan kegiatan-kegiatan rutin dalam perayaan tertentu. Karang Taruna perlu membuat usaha ekonomi produktif yang sekaligus mengembangkan kreatifitas remaja dan penanggulangan masalahmasalah sosial, baik secara preventif maupun rehabilitatif. Begitu pula dengan 


\section{A. Persamaan arahan adaptasi}

Persamaan karakter sosial kedua wilayah penelitian adalah sebagai berikut :

- Perkotaan yang erat kegotongroyongannya

- Partisipasi kegiatan sosial sedang

- Area permukiman dan persawahan terendam banjir

Sehingga arahan utama adaptasi peningkatan resiliensi sosialnya adalah :

\section{Mitigasi}

\begin{tabular}{|l|l|}
\hline a. Mempertahankan budaya & \\
gotong-royong & \\
b. Mempertahankan \& & mengoptimalkan kegiatan \\
kelompok atau komunitas & \\
\hline
\end{tabular}

Rehabilitasi

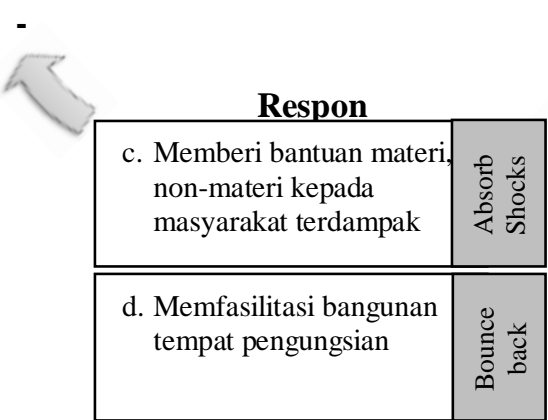

B. Arahan adaptasi wilayah perkotaan Benjeng

Karakter sosial Wilayah perkotaan

Benjeng adalah sebagai berikut :

- Keanggotaankomunitas sedang

- Kegotong-royongan masiherat

- Partisipasi kegiatan sosialsedang

- WaterborneDisease tinggi

- Pelatihan kesadaran bencana sangatrendah

- Informasi media internet sedang

Sehingga arahan utama adaptasi peningkatan resiliensi sosialnya adalah :

\section{Mitigasi}

\begin{tabular}{l|l} 
a. Koordinasi percepatan & \\
pemasangan pipa & \\
PDAM & beningkatan SDM \\
b. Peninga \\
tenaga medis
\end{tabular}

Rehabilitasi

\begin{tabular}{|c|c|}
\hline $\begin{array}{l}\text { Bantuan modal bagi } \\
\text { pedagang yang produknya } \\
\text { terendam banjir }\end{array}$ & 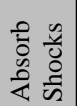 \\
\hline $\begin{array}{l}\text { Memberikan solusi } \\
\text { perbaikan kualitas air } \\
\text { sumur }\end{array}$ & 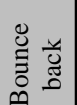 \\
\hline
\end{tabular}

Kesiapsiagaan

Pengecekan kesiapan

bidang kesehatan

mendekati bulan banjir

Pagelaran kesenian rakya wayang untuk menghibur, sosialisai dan edukasi

\begin{tabular}{|c|c|}
\hline $\begin{array}{l}\text { Penyampaian informasi } \\
\text { siaga banjir secara } \\
\text { langsung kepada seluruh } \\
\text { masyarakat melalui } \\
\text { pengeras suara mushola }\end{array}$ & 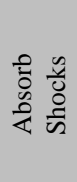 \\
\hline $\begin{array}{l}\text { Meminimalkan kontak } \\
\text { langsung anak dengan air } \\
\text { banjir }\end{array}$ & 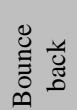 \\
\hline
\end{tabular}

C. Arahan adaptasi wilayah perkotaan Cerme

Karakter sosial wilayah perkotaan Benjeng adalah sebagai berikut :

- Kegotong-royongan masiherat

- Partisipasi kegiatan sosialrendah

- Level demokrasirendah

- Informasi media internet tinggi

Sehingga arahan utama adaptasi peningkatan resiliensi sosialnya adalah :

\section{Mitigasi}

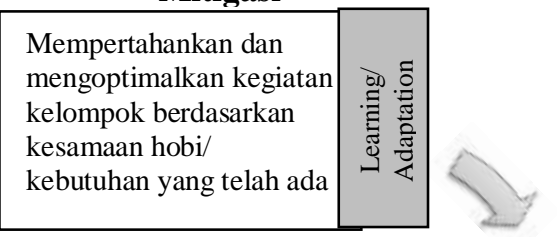

Rehabilitasi

Menyediakan tempat pegungsian (meminjamkan gedung milik pemerintah)
Kesiapsiagaan

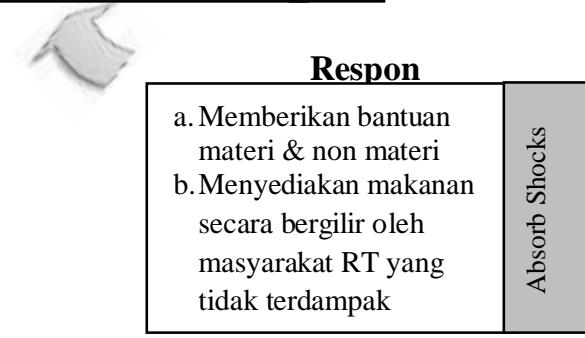




\section{KESIMPULAN}

1. Rata-rata adaptasi yang berada pada tahap mitigasi dan kesiapsiagaan merupakan upaya untuk meningkatkan kemampuan system untuk belajar dan beradaptasi (learning and adaptation).

2. Rata-rata adaptasi yang berada pada tahap respon dan rehabilitasi merupakan upaya untuk menahan perubahan dan tekanan (absorb shock) dan upaya system untuk kembali ke keadaan sebelum bencana (bounce back).

3. Mempertahankan budaya gotong royong dan memberi bantuan materi dan non materi pada masyarakat terdampak adalah adaptasi yang sangat relevan pada kedua perkotaan.

4. Karakteristik khusus dari wilayah perkotaan Benjeng adalah keanggotaan komunitas dan akses informasi melalui jaringan internet dan jumlah penyakit akibat tercemar air banjir masih dalam kategori sedang. Selain itu pelatihan kesadaran bencana tidak menjangkau masyarakat hingga ke tingkat bawah. Oleh karenanya, focus arahan adaptasi adalah :

a. Mitigasi (mitigation)

Koordinasi percepatan pemasangan pipa PDAM serta meningkatan SDM tenaga medis.

b. Kesiapsiagaan (preparedness)

Pengecekan kesiapan bidang kesehatan mendekati bulan banjir serta Pagelaran kesenian rakyat wayang untuk menghibur, sosialisai dan edukasi

c. Respon (response)

Penyampaian informasi siaga banjir secara langsung kepada seluruh serta Meminimalkan kontak langsung anak dengan air banjir

d. Rehabilitasi (rehabilitation)

Bantuan modal bagi pedagang yang produknya terendam banjir serta Memberikan solusi perbaikan kualitas air sumur

5. Karakteristik sosial khusus wilayah perkotaan Cerme adalah keikutsertaan masyarakat dalam pengambilan keputusan masih dalam kategori sedang. Dengan demikian, focus arahan adaptasi adalah :

a. Mitigasi (mitigation)

Mempertahankan dan mengoptimalkan kegiatan kelompok berdasarkan kesamaan hobi/ kebutuhan yang telah ada

b. Respon (response)

Memberikan bantuan materi \& non materi serta menyediakan makanan secara bergilir oleh masyarakat RT yang tidak terdampak

c. Rehabilitasi (rehabilitation)

Menyediakan tempat pegungsian (meminjamkan gedung milik pemerintah)

\section{DAFTAR RUJUKAN}

Aldrich, D. P. (2017). In Disaster Recovery, Social Networks Matter More Than Bottled Water and Batteries. Diakses tanggal April 24, 2017, dari www.citylab.com: http://www.citylab.com/cityfixer/2 017/02/recovering-from-disasterssocial-networks-matter-more-thanbottled-water-andbatteries/516726/

Aminudin. (2013). Mitigasi dan Kesiapsiagaan Bencana Alam. Bandung: Angkasa Bandung.

Ariantoni, Paresti, S., \& Hidayati, S. (2009). Modul Pelatihan Pengintegrasian Pengurangan Risiko Bencana (PRB) ke Dalam Sistem Pendidikan. Jakarta: Pusat Kurikulum Badan Penelitian dan Pengembangan Kementerian Pendidikan Nasional.

Barrett, C.B., \& Constas, M.A. (2013). Resilience to avoid and escape chronic poverty: Theoretical Foundations and Measurement Principles. Washington DC : Cornell University

BNPB. (2016). Dongeng, Media Edukasi Bencana Anak-Anak Sejak Dini. Diakses tanggal 31 Juli 2016 dari 
https://www.bnpb.go.id/home/detai 1/3030/home/form_ppid

Ciptaningrum, M.U., \& Pamungkas, A. (2017).Adaptasi Peningkatan Resiliensi Aspek Sosial Berdasarkan Konsep Climate and Disaster Resilience Initiative (CDRI). Surabaya: Departemen Perencanaan Wilayah dan Kota, Institut Teknologi Sepuluh Nopember.

Departemen Kesehatan RI. (2007). Buku

Saku Petugas Lapangan

Penanggulangan Krisis Kesehatan.

Jakarta : Departemen Kesehatan RI.

Evans, S.M., \& Boyte, H.C. (1992). The

Sources of Democratic Change in

America. Chicago : University of Chicago Press.

Huda, I.A.S. (2016). Bentuk-Bentuk Adaptasi Masyarakat Dalam Menghadapi Bencana Banjir (Studi Kasus di Desa Pelangwot Kecamatan Laren Lamongan). Universitas Gadjah Mada.

Imagawa S., Porter K., Sulis S., Wozniak B. (2016). Social Capital, Indigenous Community Capacity, And Disaster Management. Department of Urban and Regional Planning University Of Hawai'i.

Indawati, L. (2015). Analisis Tingkat Kerawanan Banjir dan Persepsi Masyarakat Terhadap Upaya Pengurangan Dampak Banjir di Kecamatan Baureno Kabupaten Bojonegoro. Surakarta: Program Pasca sarjana Kependidikan Universitas Sebelas Maret.

Kepmenkes

No.1653/Menkes/SK/XII/2005

tentang pedoman penanganan bencana bidang kesehatan.

Khan, H. (2008). Disaster Management Cycle - A Theoretical Approach. Institute Of Information Technology, Abbottabad, Pakistan, Associate Professor Phd Laura Giurca VASILESCU, University Of Craiova, Romania.
Nurhaimi R., \& Rahayu S. (2014). Kajian Pemahaman Masyarakat Terhadap Banjir Di Kelurahan Ulujami, Jakarta. Jurnal Teknik PWK Volume 3 Nomor 2 2014. Jurusan Perencanaan Wilayah Dan Kota, Fakultas Teknik, Universitas Diponegoro.

Peraturan Menteri Dalam Negeri No 5

Tahun 2007 tentang Pedoman Penataan Lembaga Kemasyarakatan.

Peraturan Menteri Kesehatan RI No.1018/MENKES/PER/V/2011/

MENKS/SK/V/2009 tentang

Strategi Adaptasi Sektor Kesehatan terhadap Dampak Perubahan Iklim

Perka BNPB No.7 tahun 2008 tentang Tata Cara Pemberian Bantuan Pemenuhan Kebutuhan Dasar

PMI Pusat. (2007). Panduan Kesiapsiagaan Bencana Berbasis Masyarakat Strategi dan Pendekatan. Divisi Penanggulangan BencanaPalang Merah Indonesia Pusat. Jakarta.

Sander T.H., Lowney K. (2006). Social Capital Building Toolkit (Version 1.2).

UNISDR. (2009). Terminology. Diakses tanggal 15 Februari 2017, dari UNISDR (Uniter Nations Office for Disaster Risk Reduction): http://www.unisdr.org/we/inform/t erminology

UU No.24 Th 2007 tentang Penanggulangan Bencana.

Website desa Kahuripan. (2016). Pentingnya Pembuatan Website Desa sebagai Sarana pengawasan dan Promosi. Diakses tanggal Mei 28, 2017, dari Desa Kuripan Kecamatan Penengahan Lampung Selatan: http://kuripanpenengahan.desa.id/pentingnyapembuatan-website-desa-sebagaisarana-pengawasan-dan-promosi/ 